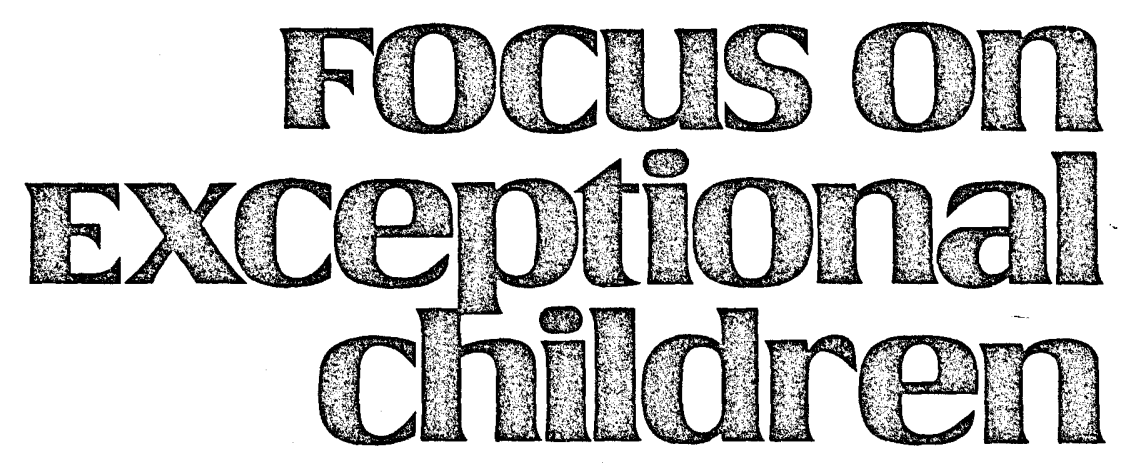

\title{
Comprehensive Curricula for Integrating Severely Disabled and Nondisabled Students
}

\author{
Mary Jo Noonan and Norma Jean Hemphill
}

Integration, from an educational perspective, means that all students have equal access to the total school environment for the purpose of achieving their educational goals. The legal, social, and educational rationales for integrating severely disabled and nondisabled students have been delineated in numerous publications (cf., Bricker, 1978; Brown et al., 1979). Federal funding of large-scale demonstration projects (e.g., Hawaii Integration Project, Kansas Integration Project) and research institutes (e.g., San Francisco State University and University of Minnesota) demonstrates governmental support of integration efforts. And a major professional organization, The Association for Persons with Severe Handicaps, has adopted a deinstitutionalization resolution proclaiming the rights of disabled students to access integrated environments in the public schools ("TASH Adopts Resolution," 1980).

Integration is more than a special education trend; it is an expression of a broader concern for safeguarding the constitutional rights of all citizens on the basis of the equal protection doctrine. Equal protection is rooted in the values of self-fulfillment and disregard of unalterable traits (H. R. Turnbull, personal communication, 1981). Self-fulfillment implies that an individual is free from unnecessary restrictions and limitations to his/her liberty. Disregard of unalterable traits means that an individual is not discriminated against (or restricted) on the basis of inborn characteristics such as sex, race, ancestry, and disability. Integration of severely disabled students addresses the values of self-fulfillment and disregard of unalterable traits by providing equal and shared access to environments, programs, and events available to nonhandicapped students.

Dr. Noonan is an Assistant Professor, Special Education, University of Hawaii at Manoa. Dr. Hemphill is affiliated with the Center for Human Growth, Honolulu.

๑ Love Publishing Company, 1984 
Equal access in an educational environment has three elements: (a) physical accessibility, (b) programmatic accessibility, and (c) affective accessibility (Stodden, 1980). Physical accessibility requires that all areas within the environment accommodate disabled students. Modifications such as ramps, rails, signs (e.g., pictures), elevators, braille markers, and so on may be necessary to accomplish physical accessibility. Programmatic accessibility requires that the same variety of school programs (e.g., homeroom, recess, lunch periods, intramurals, drama, music, art) and the same types of educational materials (e.g., library books, gym equipment, microcomputers) be available to disabled students. Affective access means that personal beliefs or stereotypes about a student or group of students do not prevent that individual or group from utilizing school environments or program resources. An affective access barrier exists if nondisabled students are never observed interacting with disabled students during shared lunch periods. Comprehensive efforts to integrate severely disabled students with their nondisabled peers must consider all three types of accessibility: physical, programmatic, and affective.

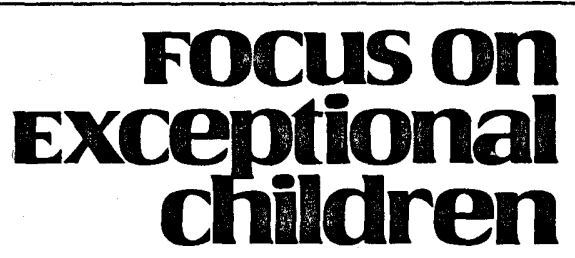

FOCUS ON EXCEPTIONAL CHILDREN (ISSN0015-5IIX) (USPS 203-360) is published monthly except June, July, and August as a service to teachers, special educators, curriculum specialists, administrators, and those concerned with the special education of exceptional children. This journal is abstracted and indexed in Exceptional Child Education Resources, and is also available in microform from Xerox University Microfilm, Ann Arbor, Michigan. Subscription rates, $\$ 18.00$ per year. Copyright $\odot$ 1984, Love Publishing Company. All rights reserved. Reproduction in whole or part without written permission is prohibited. Printed in the United States of America. Second class postage is paid at Denver, Colorado.

POSTMASTER: Send address changes to:

Love Publishing Company

Executive and Editorial Office

1777 South Bellaire Street

Denver, Colorado 80222

Telephone (303) 757-2579

\section{EDITORIAL BOARD}

Edward L. Meyen

University of Kansas
Glenn A. Vergason Georgia State University
Richard J. Whelan

University of Kansas Medical Center

\section{THE ROLE OF CURRICULA IN INTEGRATION}

Curricula generally provide the scope of instructional content, a delineation of goals and objectives, and in some instances strategies/procedures for meeting the goals and objectives. Integration curricula can address programmatic and attitudinal accessibility by providing guidelines, lessons, or activities illustrating when, where, and how to integrate severely disabled and nondisabled students. Persons involved indirectly with integration efforts (e.g., ancillary staff, parents) should be included in integration activities to enhance their respect for individual differences, improve their understanding of integration purposes, and support the generalization of positive attitudes developed through integration.

Although curricula can assist some aspects of integration, curricula cannot make an environment physically accessible to disabled persons. Physical accessibility, as mandated by law (Section 504 of PL 93-380), requires administrative decisions.

The location of classrooms for severely disabled students is one physical accessibility concern that cannot be remedied by curriculum. Classrooms for disabled students must be adjacent to or in close proximity to classrooms for regular education students of the same age. Special education classrooms should not be at the end of a hallway, in a distant wing, in a separate building, or in a remote area of the school campus.

Activities such as homeroom, lunch, recess, and extracurricular programs will be accessible to all students (disabled and nondisabled) only if they are scheduled at the same time. Scheduling barriers to integration are a physical and programmatic accessibility issue and are a function of administration rather than curriculum. Unless advanced planning for integration occurs when the school's overall schedule is developed, incompatible special education and regular education schedules may create unnecessary barriers to integration.

\section{PARAMETERS OF APPROPRIATE INTEGRATION CURRICULA}

\section{Valued Roles}

In proposing that the term social role valorization be adopted in place of normalization, Wolfensberger (1983) has argued that the ultimate goal "must be the creation, support, and defense of valued social roles for people who are at risk of social devaluation" (p. 234). Integration curricula must allow students with severe disabilities 
to assume valued social roles and participate meaningfully with their nondisabled peers. Valued roles are created by enhancing a person's social image and social competence through the use of natural settings, relationships and groups, and programs and activities.

\section{Integrative, Not Additive, Procedures}

Integrative procedures influence how something is done rather than what is done. They modify or expand upon events already occurring within the school community, whereas additive procedures are supplemental to the regular activities (Hemphill, 1981). Integrative curricula are more desirable than additive curricula because they provide a normalizing context for activities.

A 2-hour inservice training session on how to integrate severely disabled students would be an additive procedure and, therefore, less appropriate than an inservice meeting on extracurricular activities that would include recommendations and strategies for facilitating integration. Some schools provide an orientation program and booklet to incoming regular education students and their parents. Expanding the program and booklet to include disabled students and their parents is another example of a possible integrative procedure.

\section{Age-Appropriate Interactions}

Special education classes should be located on ageappropriate campuses to provide the natural environment for teaching age-appropriate social skills (Brown et al., 1979; Hamre-Nietupski \& Nietupski, 1981). Observational data of social interactions among severely disabled students and their peers indicate that peer relationships are qualitatively different from teacherchild relationships.

In an analysis of joint object orientation, joint object use, and joint intentional behaviors, Noonan \& Hemphill (1983) found that teachers are more effective than peers in getting disabled students to interact with objects (reflecting the educational nature of the interaction). Peers, however, do a much better job of maintaining students' attention to an activity. The higher frequency of joint attention with peers suggests that the friendship relationship is more social than the teacher-student dyad and may be contributing to the disabled student's social development.

\section{Communication/Interaction, Not Information}

One of the most important skills that disabled and nondisabled students can learn is to communicate with one another. Personalized learning situations have been demonstrated to result in greater acceptance by nondisabled students than information-focused procedures (Voeltz et al., 1983). Although information about disabilities may be interesting and helpful in certain respects (e.g., satisfying curiosity or discrediting unfounded stereotypes), it does not contribute to the development of positive peer interactions or attitudes.

\section{Reciprocal Relationships}

Integration curricula should foster joint and complementary participation that benefits both individuals (e.g., giving and taking, shared decision making). Friendships provide reciprocal experiences for acquiring the social and communication skills necessary to engage in mutually rewarding relationships.

In contrast, peer tutoring is a unidirectional relationship; the tutor is a helper and decision maker, and the tutee is a passive receiver. A tutoring relationship results in inequitable benefits. It reinforces the stereotype that disabled student the opportunity to contribute to the interaction. Furthermore, once a helping relationship has been established between individuals, that relationship is difficult to change to a reciprocal one (Hemphill, 1981).

\section{SOCIAL SKILLS TRAINING}

Social skills are a significant factor in predicting the success of disabled individuals in normalized environments such as kindergarten (Vincent et al., 1980), vocational settings (Johnson \& Mithaug, 1978; Niziol \& DeBlassie, 1972), and community group homes (Crawford, Aiello, \& Thompson, 1979; Jacobson \& Schwartz, 1983; Schalock, Harper, \& Genung, 1981). Integration efforts should be supported by teaching appropriate social skills to severely disabled students in the context of natural, integrated environments. As Brown and his colleagues have pointed out, functional objectives cannot be taught in segregated environments because segregated environments are unlike any natural environments (Brown et al., 1983).

\section{The Interactive Curricular Model}

The Social Skills Curricular Strategy for Students with Severe Disabilities (Noonan, Hemphill, \& Levy, 1983) is designed for implementation in integrative contexts. The curriculum is based on the Interactive Curricular Model for Life Planning (Hemphill, Noonan, \& Levy, 1983), a model consisting of three interactive components: roles, 
environments, and basic human needs (see Figure 1). Within the Interactive Curricular Model, the curriculum focuses on the social skills needed to participate in a variety of valued roles, such as work, friend, maintenance, student, and recreational/leisure roles. Social skills are learned in environments natural to the role, including domestic, vocational, educational, and community environments. Providing access to these valued roles and normalized environments through integrative curriculum can create opportunities for all students to meet the full range of human needs.

Although social skills are emphasized, social-related and task-related skills are inherent in the successful performance of every routine and activity (Hemphill, Noonan, \& Levy, 1983). These social and task skills are so intertwined that separating them is often difficult. For example, when going to the movies, one needs the taskrelated motor skills to move forward in the ticket line, the expressive communication skills to ask for a ticket, and the money skill to buy the ticket. But how one waits in the line with other people and the tone of voice one uses to address the ticket seller are the social skills of the routine. Figure 2 illustrates the complexity of this differentiation of skills.

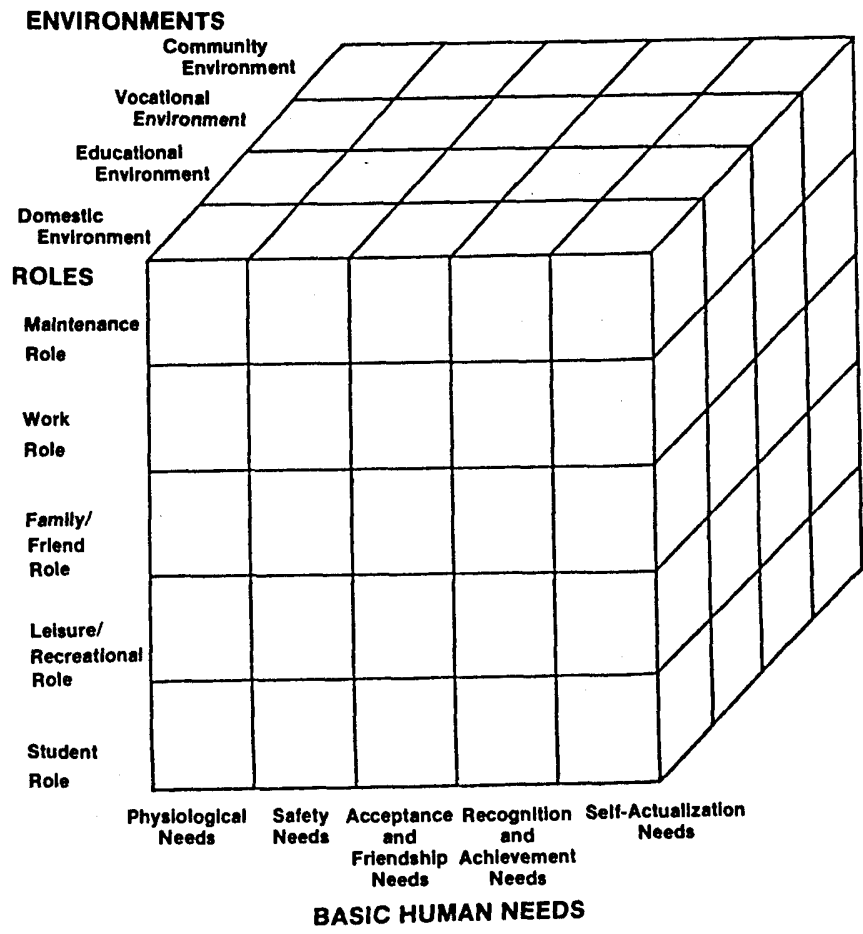

FIGURE 1

Interactive Curricular Model For Students with Severe Disabilities
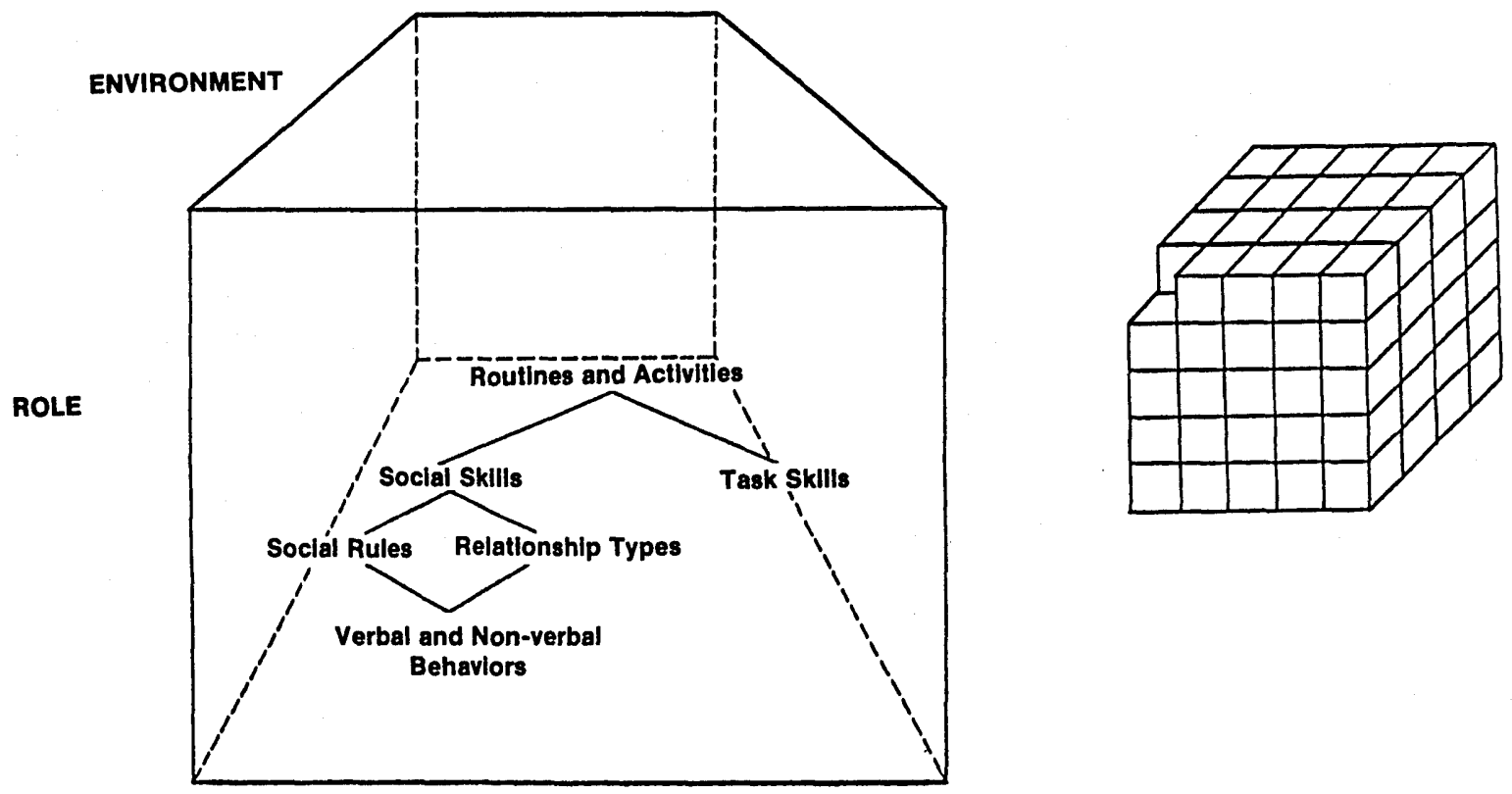

BASIC HUMAN NEEDS 


\section{Assessment of Social Skill Needs}

The curriculum strategy provides a step-by-step process for assessing social skill needs and deriving appropriate objectives through consideration of valued roles, natural environments, and basic human needs (the components of the Interactive Curricular Model). The process entails:

1. Identification of present and future roles and environments desired and valued by the disabled student, his/her parents/guardians, teacher, and society;

2. Observation of the student's present routines and activities;

3. Discrepancy analysis between the desired and the present routines and activities;

4. Selection of critical routines and activities;

5. Behavioral assessment of the social skills embedded in the critical routines and activities, and identification of appropriate instructional objectives.

Steps 1 through 4 of the assessment process narrow down and prioritize routines and activities specific to the student's needs in present and future environments. In step 5, social skill requirements are differentiated from the task skills of the priority routines and activities, and the social skills are assessed through direct observation. Figure 3 is an example of a completed social skills behavioral assessment for a priority routine of toileting. During an observation period (Part I) all behaviors are coded according to topography (e.g., formal sign language $=\mathrm{s}$ ) and categorized according to social skill functions (e.g., gains entry/greetings, initiates question/statement/ preference). The appropriateness of the response (or skill deficits) is noted in the "Post-Observation" column. Based on the post-observation comments and teacher judgments concerning the quality and nature of the observation (Part II), the assessment is summarized, and the student's major social skill needs for the routine/ activity are listed (Part III).

\section{Functional Methods of Instruction}

Following the assessment process, the Social Skills Curricular Strategy describes and provides examples of how to utilize functional methods of instruction with the objectives identified through the final step of assessment. A matrix, such as the example in Figure 4, is recommended for identifying natural situations within the ongoing routines and activities for social skills instruction. The matrix is filled in by indicating the relationship of each social skill objective (listed across the top of the matrix) and each daily routine/activity (listed down the left side of the matrix). An " $X$ " is placed in the cell if the social skill is not relevant to the corresponding routine/ activity.

Social skills instruction is then implemented in .conjunction with other instructional programs during each routine/activity, or the social skills identified for each routine/activity can be arranged in logical skill sequences and taught during the routine/activity. The Social Skills Curricular Strategy provides detailed procedures for teaching social skills in skill sequences, a curriculum approach developed by Doug Guess and his colleagues at the University of Kansas (Guess \& Noonan, 1982; Holvoet, Guess, Mulligan, \& Brown, 1980; Mulligan \& Guess, 1984).

\section{Special Friends Program}

The Special Friends Program: A Trainer's Manual for Integrated School Settings (Voeltz et al., 1983) is a transitional training program to assist social interaction among severely disabled and nondisabled students. The program has two major goals: (a) to develop positive, mutually rewarding relationships that generalize across environments and maintain across time, and (b) to support the development of social competence such that disabled and nondisabled children function successfully in integrated environments.

To achieve these goals, the Special Friends Program integrates opportunities for the development of friendships during recess and other shared activities. Not only does the program make the socially valued friendship role available to severely disabled students who would otherwise be unlikely to engage in friendship relationships, but Special Friends is also an integrative program utilizing existing school programs (e.g., recess). Extensive field testing of the Special Friends Program in Hawaii and a replication of the program in Kentucky indicate that participation in the program results in significantly more positive behaviors and attitudes among nondisabled students toward their disabled peers (Hemphill, 1983; Voeltz, 1980a, 1980b, 1982).

Nondisabled students, as well as severely disabled students, need assistance in learning how to interact with one another successfully. This issue is not resolved by simply reassuring the nondisabled students with philosophical discussions about individual differences. The Special Friends Program allows students to express their concerns through discussions of this nature, but the program emphasizes skill development.

Some of the Special Friends activities for nondisabled students are preparatory for the integrated activities. These elements of the curriculum explore topics such as 
HAWAII INTEGRATION PROJECT

Social Skills Assessment Date: $9 / 20 / 83$

student: $C$ - Peers Present: 3 adults: 1 Setting: School bathroom Routine/Activity: toileting PART I

a) In the Observation column below, code the student's soctal interaction behaviors in the context of the identified setting and routine/activity.

b) In the Post-observation column, write coments about behaviors that were not observed (or not observed at an appropriate frequency) but would be useful and/or adaptive to the setting and routine/activity. If behaviors were socially inappropriate, note the reason(s).

v: vocalization or verbalization
s: formal sign language
g: gesture/facial expression/non-verbal
communication
e: social eye contact
preceding coded behavior occurred
repeatedly
preceding coded behavior was socially
inappropriate
Rater: 77 Time Period: $910 \mathrm{am}-920 \mathrm{am}$. POST-OBSERYATION

\begin{tabular}{|c|c|c|}
\hline SOCIAL SKILL & OBSERVATION & POST-OBSERYATION \\
\hline Gains entry/greetings & $e-e-$ & should greet familiar person \\
\hline Initiates guestion/statement/preference & & $N A$ \\
\hline Responds to question/statement & $g-e-g$ & noresponse to question \\
\hline $\begin{array}{l}\text { Chooses among materials, activities, } \\
\text { etc. presented }\end{array}$ & 0 & $N A$ \\
\hline Imitates model & & NA \\
\hline Follows directions & $g-e-g-e-$ & $\begin{array}{l}\text { inotructions were hefrated with } \\
\text { physicel assietance }\end{array}$ \\
\hline Follows activity's rules & $g-0$ & must recognize indicatious of vacan \\
\hline Accepts assistance & $v, g, v, g$ & $0 . K$ \\
\hline Requests/offers assistance & $g-0$ & nest help $\omega / s 0$ \\
\hline Takes exit/farewells & & $N A$ \\
\hline
\end{tabular}

PART II

1. Was the social nature of the routine/activity passive or active?

2. Rate the student's level of social participation in the activity?

3. Was the student's social behavior "typical" of him/her?

4. Did the student demonstrate the necessary task-related skills (motor, cognitive, affective) to engage in the activity?

$\begin{array}{ll}\text { CIRCLE ONE } & \begin{array}{l}\text { active } \\ \text { high } \\ \text { nowsive }\end{array} \\ \text { yes medium } & \text { no }\end{array}$

PART III

Sunmary - major social skill needs of routine/activity:

1. greet faniliar peers encountered in the bathroom 2. gres to toilet without assistance (i.e, walke directly to stall and

3. recognizes vacant stall

4. verbally requests assistance with soap dispensec.

FIGURE 3

Sample Behavioral Assessment of a Student's Social Skills Associated with the Priority Routine of Toileting 


\begin{tabular}{|c|c|c|c|c|c|c|}
\hline \multicolumn{7}{|c|}{$\begin{array}{l}\text { HAWAII INTEGRATION PROUECT } \\
\text { SOCIal SK1lls Objectives }\end{array}$} \\
\hline $\begin{array}{l}\text { Routines/ } \\
\text { Activities }\end{array}$ & $\begin{array}{l}\text { Greets } \\
\text { faniliar } \\
\text { persons }\end{array}$ & $\begin{array}{l}\text { Recognizes } \\
\text { vacant } \\
\text { tollet } \\
\end{array}$ & $\begin{array}{l}\text { Goes to } \\
\text { tollet w/o } \\
\text { assistance } \\
\end{array}$ & $\begin{array}{l}\text { Verbally } \\
\text { requests } \\
\text { assistance }\end{array}$ & $\begin{array}{l}\text { Attend to } \\
\text { speaker when } \\
\text { spoken to }\end{array}$ & $\begin{array}{l}\text { Indicate } \\
\text { choice }\end{array}$ \\
\hline Hygiene & $\begin{array}{l}\text { Greets } \\
\text { peers }\end{array}$ & $\begin{array}{l}\text { Recognizes } \\
\text { vacant } \\
\text { tollet }\end{array}$ & $\begin{array}{l}\text { Goes to } \\
\text { toilet without } \\
\text { assistance }\end{array}$ & $\begin{array}{l}\text { Requests } \\
\text { assistance } \\
\text { w/removal of } \\
\text { tight caps }\end{array}$ & $\begin{array}{l}\text { Atcends to } \\
\text { teacher }\end{array}$ & $\begin{array}{l}\text { Selects } \\
\text { personal } \\
\text { items. } \\
\text { prefers } \\
\text { cologne }\end{array}$ \\
\hline $\begin{array}{l}\text { Street } \\
\text { Crossing }\end{array}$ & & & & $\begin{array}{l}\text { Requests } \\
\text { assistance } \\
\text { stepping } \\
\text { up/down } \\
\text { curbs }\end{array}$ & $\begin{array}{l}\text { Attends to } \\
\text { teacher }\end{array}$ & \\
\hline $\begin{array}{l}\text { Making } \\
\text { Purchases }\end{array}$ & $\begin{array}{l}\text { Greets } \\
\text { familiar } \\
\text { store } \\
\text { clerks }\end{array}$ & & & $\begin{array}{l}\text { Requests } \\
\text { assistance } \\
\text { with } \\
\text { counting } \\
\text { change }\end{array}$ & $\begin{array}{l}\text { Attends to } \\
\text { clerk at } \\
\text { checkout }\end{array}$ & $\begin{array}{l}\text { Selects } \\
\text { 1tems to } \\
\text { purchase }\end{array}$ \\
\hline $\begin{array}{l}\text { Food } \\
\text { Preparation }\end{array}$ & $\begin{array}{l}\text { Greets home } \\
\text { economic } \\
\text { teacher } \\
\text { assistants }\end{array}$ & & & $\begin{array}{l}\text { Requests } \\
\text { assistance } \\
\text { with Jar } \\
\text { lids }\end{array}$ & $\begin{array}{l}\text { Attends to } \\
\text { teacher and } \\
\text { teaching } \\
\text { assistants }\end{array}$ & $\begin{array}{l}\text { Selects } \\
\text { preferred } \\
\text { ingredients. } \\
\text { seasonings }\end{array}$ \\
\hline Lunch & $\begin{array}{l}\text { Greets } \\
\text { famillar } \\
\text { schoolmates }\end{array}$ & $\begin{array}{l}\text { Recognizes } \\
\text { vacant } \\
\text { toilet in } \\
\text { restroom }\end{array}$ & $\begin{array}{l}\text { Goes to } \\
\text { vacant } \\
\text { tollet } \\
\text { without } \\
\text { assistance }\end{array}$ & $\begin{array}{l}\text { Requests } \\
\text { assistance } \\
\text { to open } \\
\text { container }\end{array}$ & $\begin{array}{l}\text { Attends to } \\
\text { conversation } \\
\text { at lunch table }\end{array}$ & $\begin{array}{l}\text { Selects } \\
\text { type of } \\
\text { milk, veg- } \\
\text { table and } \\
\text { dessert }\end{array}$ \\
\hline Gym & $\begin{array}{l}\text { Greets gym } \\
\text { teacher and } \\
\text { new } \\
\text { classmates }\end{array}$ & $\begin{array}{l}\text { Recognizes } \\
\text { vacant } \\
\text { toflet in } \\
\text { restroom }\end{array}$ & $\begin{array}{l}\text { Goes to } \\
\text { vacant tollet } \\
\text { without } \\
\text { assistance }\end{array}$ & $\begin{array}{l}\text { Requests } \\
\text { assistance } \\
\text { shoe tying } \\
\text { \& clothes } \\
\text { changing }\end{array}$ & $\begin{array}{l}\text { Attends to } \\
\text { gym teacher } \\
\text { or peers }\end{array}$ & $\begin{array}{l}\text { Selects } \\
\text { teama tes }\end{array}$ \\
\hline Prevocational & $\begin{array}{l}\text { Greets } \\
\text { vocational } \\
\text { teacher and } \\
\text { new classmates }\end{array}$ & & & $\begin{array}{l}\text { Requests } \\
\text { assistance } \\
\text { If task } \\
\text { unknown }\end{array}$ & $\begin{array}{l}\text { Attends to } \\
\text { vocationai } \\
\text { teacher }\end{array}$ & $\begin{array}{l}\text { Selects } \\
\text { among } \\
\text { three work } \\
\text { tasks }\end{array}$ \\
\hline $\begin{array}{l}\text { Afternoon } \\
\text { Leisure } \\
\text { (home) }\end{array}$ & $\begin{array}{l}\text { Greets } \\
\text { parent and } \\
\text { sibling }\end{array}$ & $\begin{array}{l}\text { Recognizes } \\
\text { vacant tollet } \\
\text { at home }\end{array}$ & $\begin{array}{l}\text { Goes to vacant } \\
\text { tollet without } \\
\text { assistance }\end{array}$ & $\begin{array}{l}\text { Requests } \\
\text { assistance } \\
\text { changing } \\
\text { clothes }\end{array}$ & $\begin{array}{l}\text { Attends to } \\
\text { conversation } \\
\text { with parent } \\
\text { or sibling }\end{array}$ & $\begin{array}{l}\text { Selects } \\
\text { leisure } \\
\text { activity }\end{array}$ \\
\hline $\begin{array}{l}\text { Dinner } \\
\text { (home) }\end{array}$ & & & & & $\begin{array}{l}\text { Attends to } \\
\text { dinner time } \\
\text { conversation }\end{array}$ & $\begin{array}{l}\text { Selects } \\
\text { preferred } \\
\text { foods and } \\
\text { quantity }\end{array}$ \\
\hline
\end{tabular}

FIGURE 4

Sample Curriculum Sequencing Matrix Describing the Relationship Between Social Skill Objectives and Daily Routine/Activities

communicating with nonverbal children, basic sign langauge, and feelings of empathy. A session illustrating how prostheses are used as tools begins by presenting the students with a cartoon of a child who sees apples in a tree but cannot reach them. The students are asked to generate creative approaches, particularly involving the use of tools, to obtain the apples. Following a discussion of their answers, the concept of tool use is expanded to include modes of transportation. The students are guided to two major conclusions: (a) tools help us do something we couldn't otherwise do on our own, and (b) tools can help us do things more quickly or more efficiently. Finally, the term prosthesis is introduced, and a variety of prostheses used by disabled students (e.g., wheelchairs, communication boards, prone standers) are shown and discussed. 
Social, play, and leisure interchanges are the primary foci of the Special Friends Program. The integration activities usually involve turn-taking so that the activities (e.g., pinball, electronic or video games, blowing and catching bubbles) are mutually reinforcing. Because the severely disabled student's behavioral repertoire is probably quite unlike that of most of the nondisabled student's friends, the nondisabled student must learn how to interact, communicate, and play with the disabled peer. These skills must be specific to each disabled peer so that successful interactions can take place.

For the nondisabled student, this social skill training is primarily vicarious. Only initial instruction from a teacher is required; the natural cues and consequences provide the student with information to make the necessary adjustments to maintain the interaction. For the disabled participants, these didactic interactions are ideal contexts for the severely disabled participant to generalize social, communication, and leisure skills that he/ she is learning.

\section{SOCIAL STUDIES CURRICULA FOR NONDISABLED STUDENTS}

A major objective of social studies is to learn about self and others in a societal context-an objective that is easily adapted for supporting integration within a school environment. For example, the following global objectives are included in The Smallest Minority: Adapted Regular Education Social Studies Curricula for Understanding and Integrating Severely Disabled Students (Brown, Hemphill, \& Voeltz, 1982; Brown, Fruehling, \& Hemphill, 1982; Hemphill, Zukas, \& Brown, 1982):

1. Development of responsibility to self and others;

2. Development of a positive self-concept;

3. Development of decision-making and problemsolving skills;

4. Development of effective communication skills.

An integrative curriculum is developed by infusing these objectives into the regular social studies lessons.

The Smallest Minority is a series of three curriculum guides for lower elementary, upper elementary, and secondary grades. They focus on learning about self and other individuals in the school-particularly those other students who are severely disabled. The curricula do not teach students about types, causes, or symptoms of disabilities. Rather, the activities help students learn that disabled students are students like themselves, with similar needs and feelings (even though they may require adaptive equipment or specialized instruction/materials to have their educational needs met). The integration activities emphasize that students can learn about individual differences through interactions with other students in the school. The appendix of each curriculum guide includes two sections of supplementary information: Etiquette with People [who have disabilities] and Integrated Recreational Activities for Disabled and Nondisabled Peers.

The Lower Elementary Grades: Understanding Self and Others (Brown, Hemphill, \& Voeltz, 1982) has three units: (a) similarities and differences, (b) problem-solving skills and alternative methods (e.g., using prostheses as tools), and (c) alternative methods of communication (e.g., communication with sign language or communication boards).

The Upper Elementary Grades (4-6): Understanding Prejudice (Brown, Fruehling, \& Hemphill, 1982) explores the dynamics of groups and group membership. The roots of prejudice (judgments on the basis of assumption) are examined, and the privileges and responsibilities of group membership are discussed. The curriculum includes a unique role-playing activity in which the students experience actual discrimination or preferential treatment solely on the basis of whether they choose a red or black card.

The final curriculum guide in the series, The Secondary Grades (7-12): Understanding Alienation (Hemphill, Zukas, \& Brown, 1982) focuses on the examination of self and the alienation of disabled persons. One activity involves a short script in which three students assume the roles of school newspaper reporters and three students portray physically disabled students who are interviewed by the reporters. In addition to learning about personal alienation, physical and programmatic barriers that contribute to the alienation of disabled persons are studied. For a final project, students evaluate the barriers and alienation in their school and design possible solutions.

Special Alternatives: A Learning System for Generating Unique Solutions to Problems of Special Education in Integrated Settings (Fruehling, Hemphill, Brown, \& Zukas, 1981) is another example of an integrative social studies curriculum for nondisabled students. Special Alternatives is a small-group activity that instructs through the process and the content of the activity. Participation enhances the student's ability, as an individual and as a group member, to generate a large number of unique solutions to a variety of problem situations. Students confront issues and problems faced by children in special and regular education, parents, and school administrators. The curriculum guide outlines 11 categories of problems. The following are examples of questions from some of the categories: 
- Name things that students can do in school that make them feel good about themselves.

- The parents of disabled children complain that their children are not allowed to eat lunch with the regular education children. The principal replies that disabled children slow down the lunch line (can't carry their own trays, move slowly, can't give the right amount of money, etc.). What can parents and the school personnel do so that the children can all eat together?

- A child's wheelchair breaks down at school. What can the child and his/her friends do?

The learning activities are designed to teach students that problems can be solved. Generating alternatives for problem solving is helpful in developing and supporting reciprocal friendships with severely disabled students. Finding new ways to play old games so that disabled students can participate is one example.

\section{SCHOOL PERSONNEL INSERVICE CURRICULA}

The most typical method of imparting new ideas and skills to administrators, teachers, therapists, and other ancillary personnel is through inservice training. Although this may be an effective method, care should be taken to develop an integrative rather than additive inservice program. Special education teachers and regular education personnel should participate together in inservice training that addresses the needs and interests of both groups. The following inservice training modules are examples of this recommendation: The Art of Being with One Another (Yoneshige, 1983b), School Climate (Levy \& Yoneshige, 1983), Advocacy Skills (Yoneshige, 1983a), and Starting a Special Friends Program in Your School (Voeltz et al., 1983). Each of the four modules consists of four instructional hours with follow-up activities implemented by each participating teacher in his/her own classroom.

The Art of Being with One Another was designed primarily for regular education teachers but is applicable to special education teachers also. The module describes how to develop or select effective instructional materials and techniques to facilitate the acceptance of individual differences among students.

The School Climate module addresses the integration of minority or disabled students as issues that effect the total school environment. For example, the case study included in the module describes a problem situation created by a teacher's attempt to integrate severely disabled students into a regular education music class. The competencies of the module include: (a) understanding the concept of school climate, identifying its components, and analyzing its relationship to educational goals; (b) developing an awareness of one's level of influence, one's capacity to effect change, and the influence level of others; and (c) understanding how to engage others in effecting change and how to utilize systematic strategies for change.

Advocacy Skills was developed for an audience with a variety of school-related roles and the common goal of improving skills for asserting and defending student rights. The four competencies are: (a) developing an understanding of advocacy, (b) recognizing factors essential for effective advocacy in education, (c) demonstrating effective advocacy skills, and (d) recognizing factors needed for developing an integration program for severely disabled students in a regular school. Participants focus on integration and other issues that are of immediate concern to them and their school.

Starting a Special Friends Program is appropriate for teachers, related service providers, or administrators who are interested in beginning the Special Friends Program in their school. The module follows a "how to" approach, and the only requisite is that classrooms for severely disabled students be located on the regular education campus.

Inservice training activities focusing on integration often have been based on the assumption that regular education teachers need their "poor" attitude toward disabled students changed to a "good" one. When teachers interviewed in the Hawaii Integration Project were asked if they would promote integrated activities among severely disabled students and their nondisabled students, however, they indicated that they were willing to do so (Hemphill, 1983). Further, teachers seemed to prefer integrated activities initiated by other school personnel (librarian, physical education teacher, and special education teacher) occurring outside of the regular teacher's classroom. One integration activity, however, that regular teachers appear to feel comfortable enough to initiate on their own and in their classrooms is art.

Programs such as Special Friends and the adapted social skills curricula build in integration experiences and provide the teachers with supportive strategies. The result is increased interactions among disabled and nondisabled students and among special and regular education teachers. The "best" integrative learning situation for teachers may be to learn with their students as the students participate in integrated activities.

\section{PARENT PARTICIPATION}

The ultimate success or failure of integrating severely disabled and nondisabled students in the public schools 
may rest with parent participation. Parents of special education and regular education students should be informed of the purposes and goals of integration and should be active participants in planning integration activities. The development of positive parent attitudes toward integration can reinforce and support the development of positive attitudes among the students. Failure to include parents may cause misunderstandings between the school and parents and may result in opposition to integration efforts. A case study reported in the school climate curriculum (Levy.\& Yoneshige, 1983) describes an actual incident in which poor planning for integration in a music program created low morale among faculty and confusion among parents.

In the earlier discussion of parameters of integration curricula, activities such as joint special education/ regular education school orientation programs and booklets are suggested for integrative parent participation. A parent manual developed by the Regular Education for All Children with Handicaps (REACH) project recommends that parents of disabled students join their school's PTA group (Halvorsen, no date). The REACH parent manual outlines several integration presentations and activities that parents of special education students can use with PTA groups. Parent presentations may be preferable to professional presentations because parents have high credibility with other parents and are more likely to speak without jargon. "Hearing that a parent of a severely handicapped child wants his child to have the chance to learn from friends her age who are not handicapped may mean more to the average PTA member than hearing about structured social programs to increase interaction" (p. 98).

\section{INTEGRATION CURRICULA IN THE COMMUNITY}

Full integration of severely disabled and nondisabled students requires community support. Participation by parents of disabled students in the PTA is one way to address integration in the community because diverse community involvement is likely to be reflected in its membership. Specific community agencies, facilities, and programs that are particularly appropriate or interesting to disabled students may be identified for direct integration efforts (e.g., public library, neighborhood swimming pool, zoo). Community integration curricula should include awareness and information about disabled individuals, specific skill training to facilitate integration (e.g., how to communicate with persons who use communication boards), and several suggestions for appropriate integrative activities.

Honolulu Zoo Docent Training: Enhancing Integrated Zoo Experiences for Disabled and Nondisabled Children/Youth (Hemphill, Fruehling, Takemoto, Yamate, \& Zukas, 1982) is an inservice training procedure designed to help zoo docents provide integrative zoo experiences for nondisabled and disabled children/ youth. The program consists of a series of activities requiring approximately $4-1 / 2$ hours to complete. The activities are designed to help individuals examine their ideas about persons with disabilities, differentiate between a disability and a handicap, enhance their verbal descriptions of zoo experiences, learn simple sign language relevant to zoo tours, and rapidly generate alternative solutions to problematic situations that might arise in integrated settings. The manual can be easily adapted to other docent groups, such as those that serve museums, aquariums, and so on.

Many community organizations offer support to disabled persons by sponsoring parties, trips, sports events, and the like. Although these events are wellintended, the result is segregation of disabled individuals from their nondisabled peers. Community organizations should be encouraged to redirect their efforts to further community integration of disabled individuals through activities such as building a ramp into an inaccessible public library or developing a public park.

\section{SUMMARY}

Integration of severely disabled students in the public schools should involve a comprehensive curriculum approach for disabled and nondisabled students, regular and special education teachers, related service personnel, school administrators, and the community. Preparatory curriculum might include social skills training for severely disabled students or learning about individual differences in social studies for nondisabled students, but the focus of integration should be on actual integration experiences (such as Special Friends).

Curricula that are appropriate for integration must create valued roles for disabled students, provide integrative rather than additive experiences, be ageappropriate, focus on communication and interaction, and facilitate the development of reciprocal relationships. Implementing a comprehensive curriculum approach and adhering to these parameters will contribute to providing equal access for all students in school and in the community. 


\section{REFERENCES}

Bricker, D.D. (1978). A rationale for the integration of handicapped and nonhandicapped preschool children. In M.J. Guralnick (Ed.), Early intervention and the integration of handicapped and nonhandicapped children (pp. 3-26). Baltimore: University Park Press.

Brown, L., Branston, M.B., Hamre-Nietupski, S., Johnson, F., Wilcox, B., \& Gruenewald, L. (1979). A rationale for comprehensive longitudinal interactions between severely handicapped students and nonhandicapped students and other citizens. AAESPH Review, 4, 3-14.

Brown, L., Ford, A., Nisbet, J., Sweet, M., Donnellan, A., \& Gruenewald, L. (1983). Opportunities available when severely handicapped students attend chronological age-appropriate regular schools. Journal of the Association for the Severely Handicapped, 8, 16-24.

Brown, S., Fruehling, R., \& Hemphill, N.J. (1982). The smallest minority: Adapted regular education social studies curricula for understanding and integrating severely disabled students. Upper elementary grades: Understanding prejudice. Honolulu: University of Hawaii/Manoa, Hawaii Integration Project.

Brown, S., Hemphill, N.J., \& Voeltz, L. (1982). The smallest minority: Adapted regular education social studies curricula for understanding and integrating severely disabled students. Lower elementary grades: Understanding self and others. Honolulu: University of Hawaii/Manoa, Hawaii Integration Project.

Crawford, J.L., Aiello, J.R., \& Thompson, D.E. (1979). Deinstitutionalization and community placement: Clinical and environmental factors. Mental Retardation, 17, 59-63.

Frueling, R., Hemphill, N.J., Brown, S., \& Zukas, D. (1981). Special alternatives: A learning system for generating unique solutions to problems of special education in integrated settings. Honolulu: University of Hawaii/Manoa, Hawaii Integration Project.

Guess, D., \& Noonan, M.J. (1982). Curricula and instructional procedures for severely handicapped students. Focus on Exceptional Children, 14(5), 1-12.

Halvorsen, A.T. (no date). P.A.C.T.: Parents and community together. San Francisco Unified School District and San Francisco State University, Project REACH.

Hamre-Nietupski, S., \& Nietupski, J. (1981). Integral involvement of severely handicapped students within regular public schools. Journal of the Association for the Severely Handicapped, 6, 30-39.

Hemphill, N.J. (October, 1981). Application of an integrated inservice model to promote social interactions between severely handicapped and regular education students in public school settings. Paper presented at the 8th Annual Convention of the Association for the Severely Handicapped, New York.

Hemphill, N.J. (1983). Promoting the integration of severely handicapped children into school/community social systems: Final report (U.S. Department of Special Education Contract No. 300-80-0746). Honolulu: University of Hawaii/Manoa.

Hemphill, N.J., Fruehling, R., Takemoto, K., Yamate, S., \& Zukas, D. (1982). Honolulu zoo docent training: Enhancing integrated zoo experiences for disabled and nondisabled children/youth. Honolulu: University of Hawaii/Manoa, Hawaii Integration Project.

Hemphill, N.J., Noonan, M.J., \& Levy, G. (May, 1983). HIP Interactive Curriculum Model. Paper presented at the Assessment and Improvement of Related Services Workshop. Honolulu.

Hemphill, N.J., Zukas, D., \& Brown, S. (1982). The smallest minority: Adapted regular education social studies curricula for understanding and integrating severely disabled students. The secondary grades: Understanding alienation. Honolulu: University of Hawaii/Manoa, Hawaii Integration Project.

Holovoet, J., Guess, D., Mulligan, M., \& Brown, F. (1980). The individualized curriculum sequencing model II: A teaching strategy for severely handicapped students. Journal of the Association for the Severely Handicapped, 5, 337-357.

Jacobson, J.W., \& Schwartz, A.A. (1983). Personal and service characteristics affecting group home placement success: A prospective analysis. Mental Retardation, 21, 1-7.
Johnson, J.L., \& Mithaug, D.E. (1978). A replication survey of sheltered workshop entry requirements. AAESPH Review, 3, 116-122.

Levy, I., \& Yoneshige, D. (1983). School climate: Applied to integration and access of special education children in full learning environments. A Ho'okoho module. Honolulu: University of Hawaii Manoa, Hawaii Integration Project.

Mulligan, M., \& Guess, D. (1984). Using an individualized curriculum sequencing model. In L. McCormick \& R.L. Schiefelbusch, Early language intervention (pp. 299-323). Columbus, OH: Charles E. Merrill.

Niziol, O.M., \& DeBlassie, R.R. (1972). Work adjustment and the educable mentally retarded adolescent. Journal of Employment Counseling, 9, 158-166.

Noonan, M.J., \& Hemphill, N.J. (1983). Differences among joint and SPED interactions with teachers and with peers. In N.J. Hemphill, Promoting the integration of severely handicapped children into school/community social systems: Final report (U.S. Department of Education Contract No. 300-80-0746) (p. 113). Honolulu: University of Hawaii/Manoa.

Noonan, M.J., Hemphill, N.J., \& Levy, G. (1983). Social skills curricular strategy for students with severe disabilities. Honolulu: University of Hawaii/Manoa, Hawaii Integration Project.

Schalock, R.L., Harper, R.S., \& Genung, T. (1981). Community integration of mentally retarded adults: Community placement and program success. American Journal of Mental Deficiency, 85, 478-488.

Stodden, R.A. (1980). Occupational skills training materials. Boston: Commonwealth of Massachusetts, Department of Occupational Education.

TASH adopts resolution calling for abolition of institutions. (1980, January). The Association for Severely Handicapped Newsletter, p. 1.

Vincent, L. J., Salisbury, C., Walter, G., Brown, P., Gruenewald, L.J., \& Powers, M. (1980). Program evaluation and curriculum development in early childhood/special education. In W. Sailor, B. Wilcox, \& L. Brown (Eds.), Methods of instruction for severely handicapped students (pp. 303-328). Baltimore: Paul H. Brookes.

Voeltz, L.M. (1980a). Children's attitudes toward handicapped peers. American Journal of Mental Deficiency, 86, 455-464.

Voeltz, L.M. (1980b). Special Friends in Hawaii. Education Unlimited, 2. 10-11.

Voeltz, L.M. (1982). Effects of structured interactions with severely handicapped peers on children's attitudes. American Journal of Mental Deficiency, 86, 380-389.

Voeltz, L., Hemphill, N.J., Brown, S., Kishi, G., Klein, R., Fruehling, R., Levy, G., Collie, J., \& Kube, C. (1983). The Special Friends program: A trainer's manual for integrated school settings. Honolulu: University of Hawaii/Manoa, Hawaii Integration Project.

Wolfensberger, W. (1983). Social role valorization: A proposed new term for the principle of normalization. Mental Retardation, 21, 234-239.

Yoneshige, D. (1983a). Advocacy skills: Applied to integration and access of special education children in full learning environments. A Ho'okoho module. Honolulu: University of Hawaii/Manoa, Hawaii Integration Project.

Yoneshige, D. (1983b). The art of being with one another: Applied to integration and access of special education children in full learning environments. A Ho'okoho module. Honolulu: University of Hawaii/Manoa, Hawaii Integration Project.

Hawaii Integration Project curriculum materials described in this paper may be purchased by contacting Media Productions and Distributions, University of Hawaii, Castle Memorial Hall,1776 University Ave., Honolulu, HI 96822. 


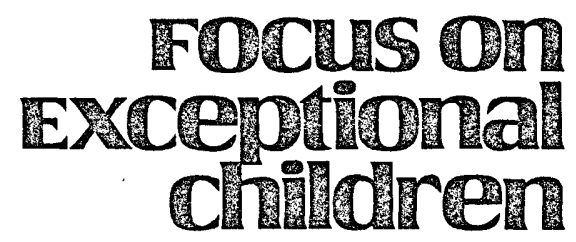

\section{computer update}

\section{By Barbara Thompson, Jerry Chaffin, and Bill Maxwell}

In follow-up to our invitation for readers to submit questions or suggestions for further exploration in this column, most of the responses concern purchasing issues. This is understandable, considering the vast and overwhelming number of choices. Some purchases have turned out to be expensive mistakes, so educators may understandably be reluctant to take the plunge. The following suggestions are based on a process that has generally led to the most successful decisions and, subsequently, to satisfied users of microcomputer technology.

Establish a committee or committees to engage in the investigation, planning, and decision-making process.

Members of these committees should represent all categorical areas, service delivery settings, and age groups served in a district. Opportunities for group members to visit other programs already using microcomputer technology should be made available. The group should identify both persons and materials that can be useful resources. Inservice training may be required,

\section{Investigate current applications related to specific} populations.

The committee should find out about special equipment, programs, and adaptations needed and available for specific areas of exceptionality. In many cases, this equipment or these programs are available only for certain computers.

Set specific objectives for how the computer is to be used and tied to the curriculum.

In a sense, an IEP should be developed for the microcomputer before selecting specific hardware and software. The ensuing examination of equipment and programs is much less overwhelming and frustrating if the purpose they are to serve has been previously defined.

Examine available software and equipment that match your objectives, and note any hardware requirements that may be indicated.

Make sure that your software is compatible with your hardware. This is a key step. For example, most educational software that is appropriate for students in special education programs uses colorful graphics, which contribute to the appeal and clarity of the program. Therefore, a color monitor would be a preferred choice. Some programs require more memory than others. Many use joysticks or paddle controls. More programs are available on floppy diskettes than on cassettes.

Develop a review procedure for making final software program decisions.

Many districts have found the development of both an evaluation form and a review procedure invaluable. When making final software selections-providing that the program is of sound technical quality and is consistent with curriculum objectives - the software ideally:

- has user flexibility; accommodates a wide range of content.

- can be adapted to two-player or team use to increase student access time.

- allows users to add their own content.

- is programmed for both keyboard and joystick/ paddle control.

- provides features (options) needed by specific populations, such as single-response opportunities (e.g., a scanning cursor and a single key that registers responses).

- has record-keeping or data management capabilities so that performance information can be saved and analyzed.

- includes support materials and suggestions for using the program and linking it to curriculum and student objectives.

- has been field-tested, evaluated, and described by reliable sources.

- has been previewed by or demonstrated to one or more staff members.

Develop strategies for training and providing ongoing support to staff.

The best hardware and software available will not be used appropriately, if at all, without staff training. This training should be planned and provided on a systematic, ongoing basis.

Plan formative evaluation procedures for assessing the impact of microcomputer technology.

Information related to the effectiveness of programs and procedures should be collected. Revisions or additions to objectives, training procedures, and future purchases will all be positively effected when they are based on data from current program applications. 